\title{
RESENHA
}

\section{A NATUREZA DO ESPAÇO. Técnica e tempo, razão e emoção.}

\author{
Milton Santos \\ Editora Hucitec, São Paulo, 1996
}

Quando lança em 1978 Por Uma Geografia Nova (da crítica da geografia a uma geografia crítica), Milton Santos proclama a necessidade de uma teoria social na Geografia. Em 1996, oferece-nos essa teoria social em A Natureza do Espaço (técnica e tempo. razão e emoção). Nesses 18 anos, toda uma progressão em livros, coletâneas, ensaios que avançam esse intuito: Por uma Geografia Nova se desdobra no Metamorfoses do Espaço Habitado (fundamentos teóricos e metodológicos da geografia), de 1988, já antes passando pelo Pensando o Espaço do Homem, de 1982, e Espaço \& Método, de 1985, e desemboca no Técnica, Espaço, Tempo (globalização e meio técnico-científico e informacional), de 1994, que antecipa A Natureza da Geografia.

Com risco de reduzi-la ao essencial, não erraria em dizer que a teoria do espaço de Milton Santos fundamentalmente é uma teoria do lugar.

Por Uma Geografia Nova contém os elementos do corpus que se oferece desenvolvido em A Natureza do Espaço. O espaço como histórico produzido, instância estrutural da totalidade, mediação determinada-determinante da história, são noções básicas do livro de 1978, que se robustecem e ganham o estatuto do edifício teórico no livro de 1996. A novidade corre por conta do papel crescente que a técnica, mas, sobretudo, o território, na sua relação ontológica com o espaço (o território é entendido como uma dimensão do espaço) e interativa com a técnica, vão adquirir na trajetória da teoria do espaço enquanto uma teoria social de Milton Santos.

Por outro lado, a teoria social exposta em A Natureza do Espaço é uma teoria da ação. O espaço é o resultado da ação e objeto articulados, potência e ato dialetica- 
mente integrados num sistema (palavra perigosa). Não se trata de uma teoria da ação pura. A ação exprime-se e se realiza no objeto. O objeto tem autonomia de existência, mas não tem autonomia de significação. O que ele é, vem das diferentes relações que mantém com o todo. A ação é quem lhe dá essa ligação e sentido, dado o seu caráter de intencionalidade, uma essencialidade portada pela técnica na forma da divisão do trabalho e que liga ação e objeto numa relação de sujeito-objeto.

Condição epistêmica, Milton Santos reolha por conseguinte a técnica, ao tempo que geograficamente a reinventa. Mais que artefato ou mediação na relação homem-meio, a técnica é em Milton Santos o processo constitutivo do território, técnica e território vivendo uma relação recíproca de constituição. Não há território sem ação técnica, e não há técnica fora de um território. Daí que a técnica só exista como meio-técnico.

A inflexão dialética é o movimento de diversificação da natureza, processo mediante o qual a natureza se renova pela modificação dos seus aspectos, renovando sua identidade, e à qual o homem superpõe a divisão do trabalho (natureza natural e natureza socializada do livro de 1978, reinventadas no de 1996). A totalidade tão buscada pelo geógrafo é não mais então que uma dialética de diversidadeunidade, onde cada modo de diversificação sucede um outro modo de diversificação, a diversidade se resolvendo na unidade e a unidade se reabrindo na diversidade, numa dialética de trocas de posição constantes sobre a qual a ação humana intervém e cujo resultado é o lugar.

O lugar é, assim, o ponto do recorte territorial por cujo intermédio a pluralidade total dos elementos encontra sua síntese. E sobre cujo suporte a técnica determinase como território e o território determina-se como técnica, território e técnica integralizando-se num meio técnico (expressão que sugere um feliz resgate do gênero de vida de La Blache, numa ótica ao mesmo tempo clássica e nova da relação homem-meio).

Síntese onde o objeto ganha significação (deixa de ser coisa, dado da natureza, e vira objeto, dado da história humana), o lugar reúne-se aos outros lugares e vê no seu conteúdo e interior definir-se o processo da produção técnica do espaço.

Desse modo, a história do espaço coincide e se revela na história da técnica, e vice-versa, cada mudança na divisão do trabalho presenciando a recriação do espaço.

De início, a técnica exprime-se como meio técnico, estágio em que é um prolongamento do corpo e potencialidade da ação imediata dos homens. Mais adiante, já num estado da dimensão econômica ampliado sobretudo no plano da esfera da circulação, evolui para tornar-se um meio técnico-científico. Por fim, chega aos dias de hoje, o tempo do espaço construído como uma universalidade empírica, e tornase meio técnico-científico e informacional.

Cada etapa conhece um lugar. Assim, do lugar do meio técnico ao lugar do meio técnico-científico e informacional, a configuração geográfica evolui do espaço singular ao espaço recortado na fragmentação da horizontalidade e verticalidade do mundo global de hoje. 
A teoria do espaço afirma-se então como uma teoria do lugar. Um discurso capaz de recuperar a dialética das interações, desaparecida na síntese das velhas teorias do espaço genérico ou ilhado da teoria regional; rejuvenescer o imenso repertório vocabular perdido na dissolução das identidades (espaço, escala, distâncias são verbetes que nem mais fazem parte dos dicionários de geografia, migrados para os dicionários de cartografia, onde tão somente aparecem); e retomar com sucesso o velho projeto de unir numa só idéia-força sociedade e natureza como discurso teórico da ação geográfica.

Fortemente influente nas pesquisas entre os geógrafos da chamada vertente humana, a teoria da ação de Milton atingirá cedo ou tarde aqueles que voltados para a chamada geografia física carecem da visão unitária dos próprios processos naturais, e ainda não descobriram-na na categoria totalizadora do lugar. Tal como Milton Santos a propõe e entende. Ao menos, oferece ao bom debate.

(Ruy Moreira) 